\title{
The Anticancer and Anti-inflammatory Effects of Centaurea solstitialis Extract on Human Cancer Cell Lines
}

\section{İnsan Kanser Hücre Hatları Üzerinde Centaurea solstitialis Özütünün Anti- Kanser ve Anti-İnflamatuar Etkileri}

\author{
(D) Mehlika ALPER1 1 (D) Hatice GÜNEŞ2* \\ 1Muğla Sıtkı Koçman University, Department of Molecular Biology and Genetics, Muğla, Turkey \\ 2Muğla Sıtkı Koçman University, Department of Biology, Division of Molecular Biology and Biotechnology, Muğla, Turkey
}

\begin{abstract}
Objectives: Natural products originating from plants have been used for many years in the treatment of various diseases, including cancer. Centaurea solstitialis subsp. solstitialis is used in Turkish folk medicine. This study was the first to determine the in vitro biological effects of ethanolic extract from the flowering parts of $C$. solstitialis L. subsp. solstitialis collected from Muğla Province.

Materials and Methods: The cytotoxic effect was evaluated against Daudi, A549, and HeLa cancer cells and one normal BEAS-2B cell line using the MTT (3-(4,5-dimethylthiazol-2-yl)-2,5- dipenyltetrazolium bromide) assay. Flow cytometric analysis and the caspase-3 activity assay were performed to detect apoptotic cell death. Angiogenic factor [vascular endothelial growth factor (VEGF)] secretion and the release of interleukin (IL)-1 $\alpha, \mathrm{IL}-6$, and tumor necrosis factor (TNF)- $\alpha$ by cells treated with the extract were measured using enzyme-linked immunosorbent assay.

Results: The extract exhibited cytotoxic effects against all the cancer cell lines used but HeLa and Daudi were the most sensitive cells, with $\mathrm{IC}_{50}$ values of $63.18 \mu \mathrm{g} / \mathrm{mL}$ and $69.27 \mu \mathrm{g} / \mathrm{mL}$, respectively. Selective cytotoxicity was observed between the HeLa and normal BEAS-2B cell lines. The extract arrested the cell cycle at the S and G2 phases. In addition, apoptotic cell death was detected in HeLa and A549 cells. Moreover, the plant extract caused a significant decrease in VEGF secretion in A549 cells and a fluctuation in IL-1 $\alpha$, IL-6, and TNF- $\alpha$ secretion in A549 and Daudi cells. Conclusion: These observations suggest that the flowering parts of $C$. solstitialis may be a potential source in the development of natural drugs for the treatment of cancer and modulation of cytokine secretion.
\end{abstract}

Key words: Centaurea solstitialis, cancer cell lines, anti-cancer, anti-inflammatory

öz

Amaç: Bitkilerden elde edilen doğal ürünler, kanser dahil çeşitli hastalıkların tedavisinde uzun yıllardır kullanılmaktadır. Centaurea solstitialis subsp. solstitialis'in Türk geleneksel tıbbında yeri olduğu bilinmektedir. Bu araştırma, Muğla ilinden toplanan C. solstitialis'in çiçekli kısımlarından elde edilen etanolik özütün in vitro biyolojik etkilerini belirleyen ilk çalışmadır.

Gereç ve Yöntemler: Özütün Daudi, A549 ve HeLa kanser hücrelerine ve normal BEAS-2B hücre hattına karşı sitotoksik etkisi MTT (3-(4,5dimetiltiyazol-2-il)-2,5-dipeniltetrazolyum bromür) testi ile belirlendi. Apoptotik hücre ölümü akış sitometri analizi ve kaspaz-3 aktivite deneyleriyle araștırıldı. Özüt ile muamele edilen hücreler tarafından üretilen anjiyojenik faktör [vasküler endotel büyüme faktörü (VEGF)] salınımı ve sitokinlerden interlökin (IL)-l $\alpha$, IL-6 ve tümör nekroz faktör (TNF)- $\alpha$ 'nın salınımı enzim bağıı immünosorbent deneyi testleriyle ölçüldü.

Bulgular: Bitki özütü kullanılan tüm kanser hücre hatlarına karșı sitotoksik etki gösterirken, özüte karşı en duyarlı hücrelerin $63.18 \mu$ g/mL and 69.27 $\mu \mathrm{g} / \mathrm{mL}$ olan IC ${ }_{50}$ değerleri ile sırasıyla HeLa ve Daudi hücreleri olduğu gözlendi. Seçici sitotoksisite HeLa ve normal BEAS-2B hücre hatları arasında tespit edildi. Bitki özütü S ve G2 fazlarında hücre döngüsü arrestine yol açtı. Buna ilave olarak, HeLa ve A549 hücrelerinde apoptotik hücre ölümü kaydedildi. Ayrıca bitki özütü A549 hücrelerinin VEGF salgılamasında anlamlı bir düșüșe yol açarken, A549 ile Daudi hücrelerinin IL-la, IL-6 ve TNF- $\alpha$ salgılamasında önemli değişime neden oldu.

Sonuç: Bu bulgular kanser tedavisi ve sitokin salgısının modülasyonunda gerekli olan doğal ilaçların geliştirilmesi için C. solstitialis'in çiçekli kısımlarının potansiyel bir kaynak olabileceğini göstermektedir.

Anahtar kelimeler: Centaurea solstitialis, kanser hücre hatları, anti-kanser, anti-inflamatuar

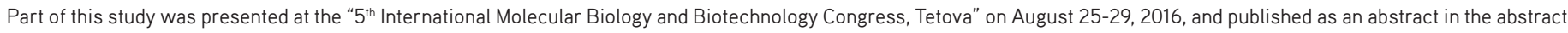
book pp 60.

*Correspondence: E-mail: haticegunes@mu.edu.tr, Phone: +90 5342821133 ORCID-ID: orcid.org/0000-0001-5191-365X

Received: 04.05.2018, Accepted: 24.05.2018

-Turk J Pharm Sci, Published by Galenos Publishing House. 


\section{INTRODUCTION}

Cancer is one of the most common diseases in both developed and developing countries. Plant products have been used throughout history to treat and prevent diseases because of their large number of different phytochemicals with different biological activities.' In fact, the compounds derived from plants play an important role in the development of anticancer agents to be used in clinical practice. ${ }^{2}$ Since substantial evidence has proved that plant secondary metabolites are a potential source of anticancer compounds and cancer cells may develop resistance to existing drugs, today extensive research is being carried out all over the world to discover new plant species with anticancer properties.

Cancer is a multistage disease. Angiogenesis, defined as the formation of new blood vessels, is an essential process in tumor development and prevention of tumor vasculation is a crucial strategy in cancer treatment. ${ }^{3,4}$ Even though there are a variety of angiogenic factors, vascular endothelial growth factor (VEGF) is a key regulator of angiogenesis. Increased VEGF secretion promotes invasion and metastasis and so targeting of VEGF is pivotal in the prevention of tumor metastasis. Therefore, the discovery of a new plant extract with anti-angiogenic activity is necessary to serve as an alternative to toxic chemotherapeutics.

Inflammation is a common cause of many diseases and alone it is not sufficient to cause cancer, but epigenetic events and mutations caused by environmental exposure or immune modulation contribute significantly to the cancer process. ${ }^{5}$ In addition, the cytokine release-mediated inflammatory mechanisms were reported to facilitate cancer metastasis. ${ }^{6}$ Various plants or their bioactive compounds can inhibit or stimulate different enzymes associated with inflammatory and immune response regulating pathways. ${ }^{7}$ Because antiinflammatory drugs may be effective in cancer therapy or prevention, ${ }^{8}$ it is important to evaluate the anti-inflammatory potential of plant extracts as well.

The genus Centaurea L., belonging to the family Asteraceae, is the third largest genus in Turkey. ${ }^{9}$ Some Centaurea species are used as remedies against various diseases in Turkish folk medicine. ${ }^{10}$ Centaurea solstitialis is known in Turkish as "gelin dikeni" and it has been used to treat hemorrhoids, peptic ulcers, common colds, ${ }^{11,12}$ malaria, ${ }^{13}$ and herpes infections around the lips of children. ${ }^{14}$ Previous studies examined the pharmacological and biological properties of Centaurea species and some Centaurea species exhibited cytotoxic effects against some cancer cell lines. ${ }^{15}$ The major constituents of Centaurea species were reported to be sesquiterpene lactones, flavonoids, and fatty acids. ${ }^{16,17}$ Nevertheless, to the best of our knowledge, there were no adequate reports about the anticancer or antiinflammatory effects of $C$. solstitialis. Therefore, the present study has scientific importance for the anticancer and antiinflammatory potential of ethanolic extract from the flowering parts of $C$. solstitialis collected from Muğla.

\section{MATERIALS AND METHODS}

\section{Plant material}

The plant $C$. solstitialis was collected during the flowering period from June to July 2015 from Muğla, in the southwest of Turkey. The plant species was identified in the Herbarium Laboratory, Department of Biology, Muğla Sıtkı Koçman University.

\section{Plant extraction}

The flowering parts of $C$. solstitialis were washed with distilled water and air-dried under shade for about 15 days. Air-dried flowers were ground into powder in a porcelain mill. The powder (10 g) was soaked in absolute ethanol ( $96^{\circ}$, Merck, USA) and placed in a Soxhlet apparatus for $10 \mathrm{~h}$ to obtain ethanolic extract. After filtration of the extract using Whatman filter paper no. 1, the ethanol was removed using a rotary evaporator (IKA, RV 10, USA). The solvent was evaporated by keeping the extracts at $37^{\circ} \mathrm{C}$ for 7 days. The powdered crude extract was stored at $4^{\circ} \mathrm{C}$ in an air-tight container until used. The extract was dissolved in 10\% dimethyl sulfoxide (DMSO) as stock solution and further diluted to obtain working solutions. DMSO in the final concentrations of the extract was less than $1 \%$ and showed no effect on the examined parameters.

\section{Cell lines and culture conditions}

Daudi (Burkitt's lymphoma, CCL-213), A549 (lung carcinoma), HeLa (cervix adenocarcinoma), and BEAS-2B (normal bronchial epithelium) cell lines were originally obtained from ATCC. The cells were maintained in RPMI 1640 medium premixed with stable L-glutamine (Biochrom, Germany) and supplemented with 10\% heat inactivated fetal bovine serum (Biochrom, Germany), penicillin (100 U/mL), and streptomycin sulfate (100 $\mathrm{mg} / \mathrm{mL}$ ) (Biochrom, Germany). All cell lines were incubated in a humidified atmosphere of $5 \% \mathrm{CO}_{2}$ and $95 \%$ air at $37^{\circ} \mathrm{C}$.

\section{In vitro cytotoxicity assay}

The cytotoxic effects of ethanolic extracts from the flowering parts of C. solstitialis on Daudi, A549, HeLa, and Beas-2B were determined by MTT (3-(4,5-dimethylthiazol-2-yl)-2,5dipenyltetrazolium bromide) assay. In this assay, the reduction of yellow soluble MTT to insoluble blue formazan crystals by mitochondrial dehydrogenase reflects cell viability. ${ }^{18}$ A total of $4 \times 10^{3}$ cells/well were seeded in 96-well plates (Greiner, Germany) in triplicate and incubated for $24 \mathrm{~h}$. Plant extracts were added to the wells at 7 different final concentrations between $1000 \mu \mathrm{g} / \mathrm{mL}$ and $15.625 \mu \mathrm{g} / \mathrm{mL}$ followed by incubation for $72 \mathrm{~h}$. Then $10 \mu \mathrm{L}$ of $5 \mathrm{mg} / \mathrm{mL}$ MTT reagent (Applichem, USA) in phosphate-buffered saline (PBS) was added to each well. After $4 \mathrm{~h}$ of incubation, the medium was gently discarded and $100 \mu \mathrm{L}$ of pure DMSO was added to each well to dissolve the formazan blue crystals formed in the cells. The absorbance of reduced MTT in each well was measured at $540 \mathrm{~nm}$ using a microplate reader (Thermo Scientific, Multiskan FC, USA). The cytotoxic effects of the extracts were determined by comparing the optical density of treated cells against that of untreated cells. 


\section{Cell cycle analysis}

Cells at $5 \times 10^{5} /$ well were seeded in 6 -well plates and treated with plant extracts at $500 \mu \mathrm{g} / \mathrm{mL}$ and $200 \mu \mathrm{g} / \mathrm{mL}$ for $24 \mathrm{~h}$. After treatment, the cells were washed with ice-cold PBS, fixed in 4 $\mathrm{mL}$ of absolute ethanol, and stored at $-20^{\circ} \mathrm{C}$ for $48 \mathrm{~h}$. After that, the cells were centrifuged at $1200 \mathrm{rpm}$ for $10 \mathrm{~min}$ at $4^{\circ} \mathrm{C}$ and the cell pellets were washed in ice-cold PBS. The cells were resuspended in $1 \mathrm{~mL}$ of PBS containing $0.1 \%$ ( $\mathrm{v} / \mathrm{v}$ ) Triton X-100 (Amresco, USA) and then $100 \mu \mathrm{L}$ of RNase $A(200 \mu \mathrm{g} / \mathrm{mL})$ (Applichem, USA) was added to each of the cell suspensions. After incubation for $30 \mathrm{~min}$ at $37^{\circ} \mathrm{C}, 100 \mu \mathrm{L}$ of propidium iodide (PI) $\left(1 \mathrm{mg} / \mathrm{mL}\right.$ in $\left.\mathrm{ddH}_{2} \mathrm{O}\right)$ was added to each cell suspension and the cells were incubated in the dark for $15 \mathrm{~min}$ at room temperature. The cells were analyzed by BD FACSCanto flow cytometer using ModFit LT 3.0 software for cell cycle phases.

\section{Apoptosis assay}

Exponentially growing A549 and HeLa cells were cultured at $5 \times 10^{5}$ cells/well in 6-well plates (Greiner, Germany) and incubated for $24 \mathrm{~h}$. The cells were treated with plant extract at final concentrations of $200 \mu \mathrm{g} / \mathrm{mL}$ and $500 \mu \mathrm{g} / \mathrm{mL}$ for $24 \mathrm{~h}$. Annexin V-FITC/PI staining was carried out using the Annexin V-FITC Apoptosis Detection Kit (eBioscience, USA) protocol. Briefly, treated cells were washed with PBS, trypsinized, washed, and resuspended in binding buffer. Then $5 \mu \mathrm{L}$ of Annexin V-FITC and $10 \mu \mathrm{L}$ of PI at $20 \mu \mathrm{g} / \mathrm{mL}$ were added to each cell suspension and the cells were incubated for $15 \mathrm{~min}$ in the dark. After $500 \mu \mathrm{L}$ of binding buffer was added, 10,000 cells per group were analyzed by flow cytometry (BD FACSCanto A, BD Biosciences) using BD FACSDiva software v6.13.

\section{Caspase-3 activity assay}

Caspase-3 activity of the cell lysates was determined by colorimetric assay kits (Abcam, Cambridge, UK). A549 and HeLa cells were plated at $2 \times 10^{6}$ cells/well in 6 -well plates and incubated for $24 \mathrm{~h}$. Then the cells were treated with plant extract at $500 \mu \mathrm{g} / \mathrm{mL}$ for $36 \mathrm{~h}$. After centrifugation, the cells were resuspended in $50 \mu \mathrm{L}$ of cell lysis buffer and incubated on ice for $10 \mathrm{~min}$. The cell lysates were centrifuged at 10.000 $\times \mathrm{g}$ for $1 \mathrm{~min}$ and the protein concentration of each cell lysate was determined by Bradford assay (1976). ${ }^{19}$ Later, $200 \mu \mathrm{g}$ of protein from each sample was mixed with $50 \mu \mathrm{L}$ of $2 \mathrm{X}$ reaction buffer containing $10 \mathrm{mM}$ DTT and $5 \mu \mathrm{L}$ of the caspase- 3 substrate ( $4 \mathrm{mM}$ DEVD-p-NA), followed by incubation at $37^{\circ} \mathrm{C}$ for 2 h. Absorbance of $p-N A$ light emission was read at 405 $\mathrm{nm}$ in a microplate reader. Fold increase in caspase- 3 activity was determined by comparing the absorbance of $\mathrm{p}-\mathrm{NA}$ from an apoptotic sample with that of untreated control cells.

\section{Quantitative detection of human VEGF by enzyme-linked immunosorbent assay}

To determine the effect of plant extract on VEGF secretion, A549 cells were cultured at a density of $2 \times 10^{5}$ cells/well in a 6 -well plate and incubated for $1 \mathrm{~h}$. Then the cells were treated with plant extract at $200 \mu \mathrm{g} / \mathrm{mL}$ and incubated for $6 \mathrm{~h}$. The supernatants were collected after centrifugation and stored at $-20^{\circ} \mathrm{C}$ until analysis. The untreated cells served as the control.
The concentrations of VEGF in the cell culture supernatants were detected by ELISA as described in the manufacturer's procedure (VEGF ELISA kit; Boster Biological Technology, USA). The absorbance of each well was measured using a microplate reader at $450 \mathrm{~nm}$ within $30 \mathrm{~min}$. The VEGF concentrations of the cell culture supernatants were interpolated from the standard curve.

Quantitative detection of human interleukin-1 $\alpha$, interleukin-6, and tumor necrosis factor- $\alpha$ by ELISA

In order to examine the effects of plant extract on inflammation, $2 \times 10^{5}$ cells/well of $A 549$ or Daudi cells were plated in triplicate in 6-well plates. The cells were treated with $200 \mu \mathrm{g} / \mathrm{mL}$ C. solstitialis extract for $6 \mathrm{~h}$ or left untreated to serve as the control. The supernatants were collected and $100 \mu \mathrm{L}$ of each supernatant was tested for inflammatory cytokine production by ELISA based on the manufacturer's instructions using commercial human ELISA kits for interleukin (IL)-1 $\alpha, \mathrm{IL}-6$, and tumor necrosis factor (TNF)- $\alpha$ (Boster Biological Technology, USA). The amount of each cytokine in the supernatants was calculated from the formula of the calibration curve of standard cytokine.

\section{Statistical analysis}

The data were analyzed using GraphPad Prism 7.0 (GraphPad Software, Inc., San Diego, CA, USA). Comparisons of treatments among the groups were performed using one-way or two-way ANOVA and post-hoc analysis. Significance was presented as ${ }^{* * *}(p<0.01)$ and $* * * *(p<0.0001)$. The data are the mean \pm standard deviation of three replicates.

\section{RESULTS}

Cytotoxic activity of plant extract on different cancer cell lines The cytotoxicity of the crude ethanolic extract from the flowering parts of $C$. solstitialis at seven different concentrations was investigated on the A549, Daudi, HeLa, and Beas-2B cell lines to determine the $I_{50}$ value $(\mu \mathrm{g} / \mathrm{mL})$ that causes $50 \%$ cell death. The results demonstrated that the percentage of viable cells changed according to the cell lines used (Figure 1). The viability of all the cancer cells was significantly reduced by the extract in a concentration-dependent manner. However, the extract at concentrations of 15.6 and $31.2 \mu \mathrm{g} / \mathrm{mL}$ did not exert significant cytotoxicity on the normal BEAS-2B cell line, indicating the selectivity of the extract against cancer cells (Figure 1d). The highest cytotoxicity, with an $\mathrm{IC}_{50}$ value of 63.18 $\mu \mathrm{g} / \mathrm{mL}$, was observed against HeLa cells (Figure 1c), whereas the $I_{50}$ values of $A 549$ and Daudi cells were $252.5 \mu \mathrm{g} / \mathrm{mL}$ and $69.27 \mu \mathrm{g} / \mathrm{mL}$, respectively (Figure 1a and 1b). On the other hand, the extract exhibited a lower cytotoxic effect on normal BEAS2B cells, with an $\mathrm{IC}_{50}$ value of $75.25 \mu \mathrm{g} / \mathrm{mL}$, when compared with the effects on the HeLa and Daudi cancer cell lines (Figure 1). In other words, in terms of cytotoxicity, HeLa and Daudi cells were the most sensitive cell lines against the extract.

\section{The effect of plant extract on cell cycle distribution}

Since the plant extract at $250 \mu \mathrm{g} / \mathrm{mL}$ was cytotoxic against all the cell lines tested, the rest of the analyses for different 
parameters were performed with the extract at $200 \mu \mathrm{g} / \mathrm{mL}$ and $500 \mu \mathrm{g} / \mathrm{mL}$. The changes in cell-cycle progression of the HeLa and A549 cancer cells after treatment with plant extracts at $200 \mu \mathrm{g} / \mathrm{mL}$ and $500 \mu \mathrm{g} / \mathrm{mL}$ for $24 \mathrm{~h}$ were analyzed using flow cytometry with Pl staining. Plant extract at $200 \mu \mathrm{g} / \mathrm{mL}$ showed virtually no effect in the cell cycle phases of HeLa cells (Figure 2A; a, b, d). At $500 \mu \mathrm{g} / \mathrm{mL}$, there was a slight increase in the percentage of HeLa cells in the G2 phase and it was

A

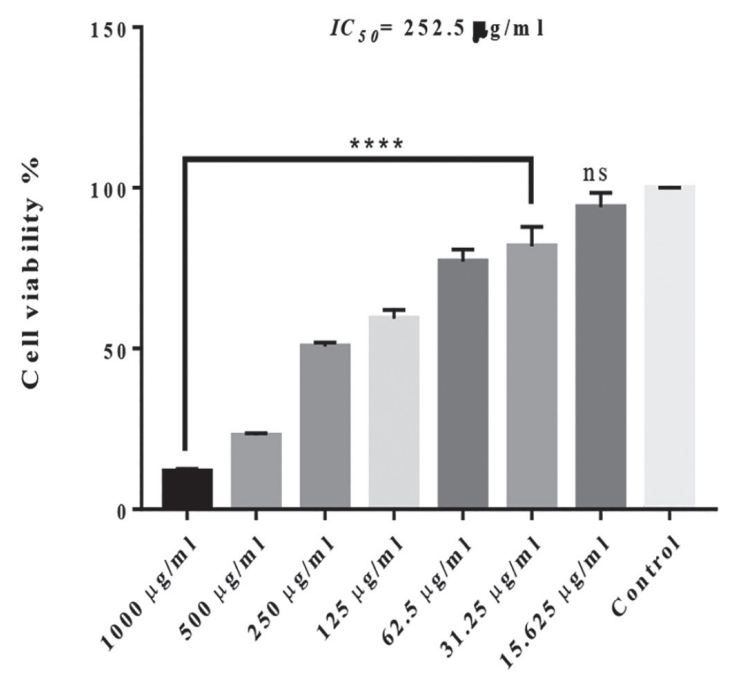

Extract concentration accompanied by a decrease in the percentage of cells in the G1 phase from $48.97 \%$ to $41.57 \%$ (Figure $2 \mathrm{~A}$; a, c, d). In addition, treatment of A549 cells with plant extracts at 200 and $500 \mu \mathrm{g} /$ $\mathrm{mL}$ for $24 \mathrm{~h}$ resulted in $7.1 \%$ and $12.5 \%$ increases in cells in the $\mathrm{S}$ phase, respectively, and it caused a concomitant decrease in the percentage of cells in the G1 phase (Figure 2B; a-d). Furthermore, the percentage of $\mathrm{G} 2$ phase cells increased from $4.8 \%$ to $15.6 \%$ and $9.6 \%$ in A549 cells treated with the extract

C

HeLa $72 h$

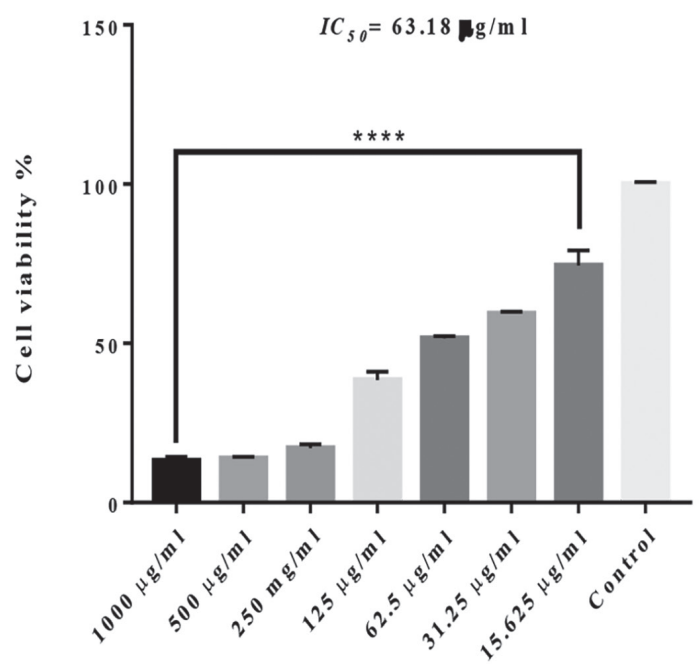

Extract concentration
B

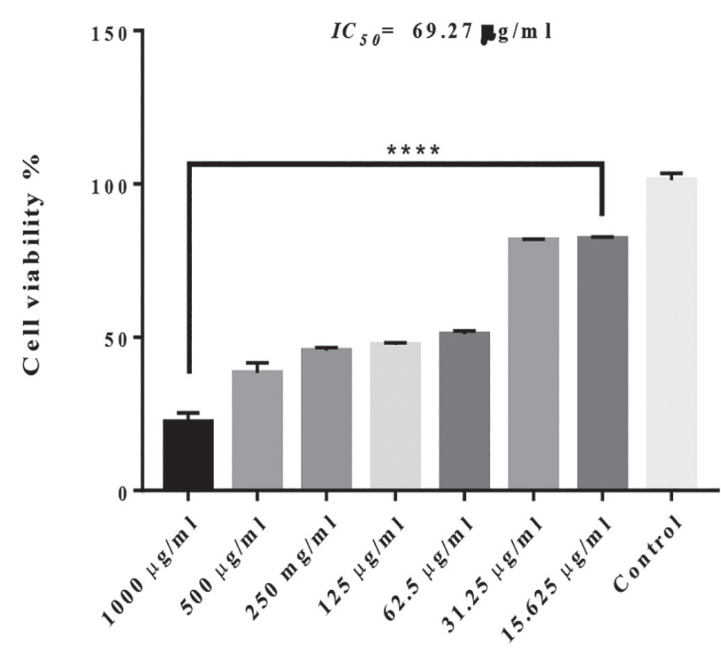

Extract concentration

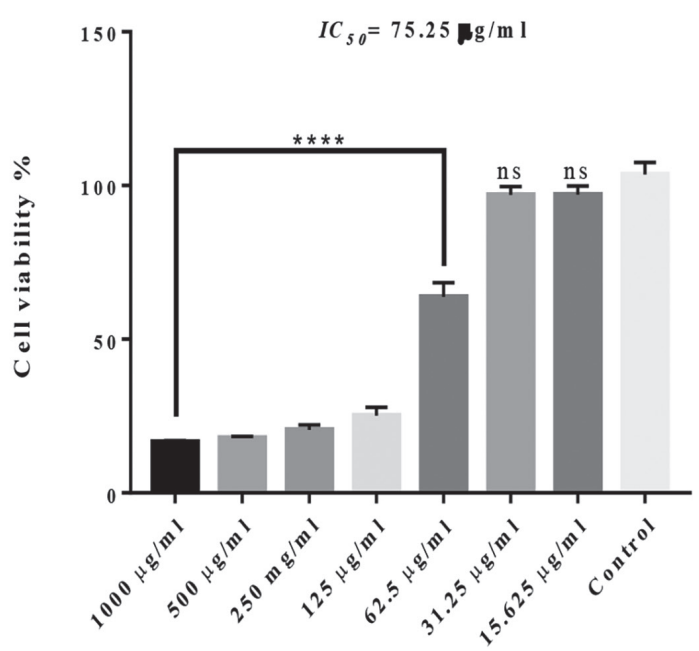

Extract concentration

Figure 1. Cytotoxic activity of plant extract against different cancer cell lines. Human cancer cells A549 (A), Daudi (B), HeLa (C), and Beas-2B (D) were treated with ethanolic extract from the flowering parts of Centaurea solstitialis for $72 \mathrm{~h}$. Cell viability was determined based on the MTT assay. Data are the means ( \pm standard deviation) of three independent experiments 
at 200 and $500 \mu \mathrm{g} / \mathrm{mL}$, respectively. These results suggest that the plant extract might inhibit cell proliferation by arresting both cells especially in the $\mathrm{G} 2$ phase.

\section{Apoptotic effect of plant extract}

As cell cycle regulation and apoptosis are closely related, disruption of cell cycle progression may result in apoptotic/ necrotic death. ${ }^{20}$ Therefore, it was investigated whether or not apoptosis was initiated in cells treated with plant extracts for 24 h. As shown in Figure 3A, the percent of apoptotic HeLa cells (quadrants 2 and 4 ) increased from $1 \%$ to $9.3 \%$ and $11.8 \%$ after treatment with the extract at 200 and $500 \mu \mathrm{g} / \mathrm{mL}$, respectively (Figure 3A; a-d). In addition, the percentage of apoptotic A549 cells (quadrants 2 and 4 ) increased from $3.7 \%$ to $4.5 \%$ and $31.8 \%$ after treatment with 200 and $500 \mu \mathrm{g} / \mathrm{mL}$ extract, respectively (Figure 3B; a-d). These findings demonstrate that the plant extract at $500 \mu \mathrm{g} / \mathrm{mL}$ induces apoptosis in both cell lines, especially in A549. These data were consistent with the results obtained from the cell cycle analysis.

A
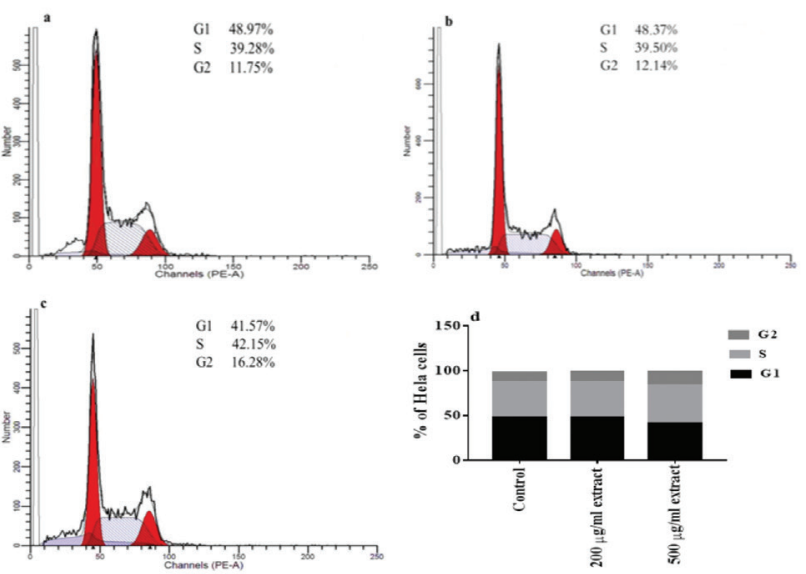

$\mathbf{B}$
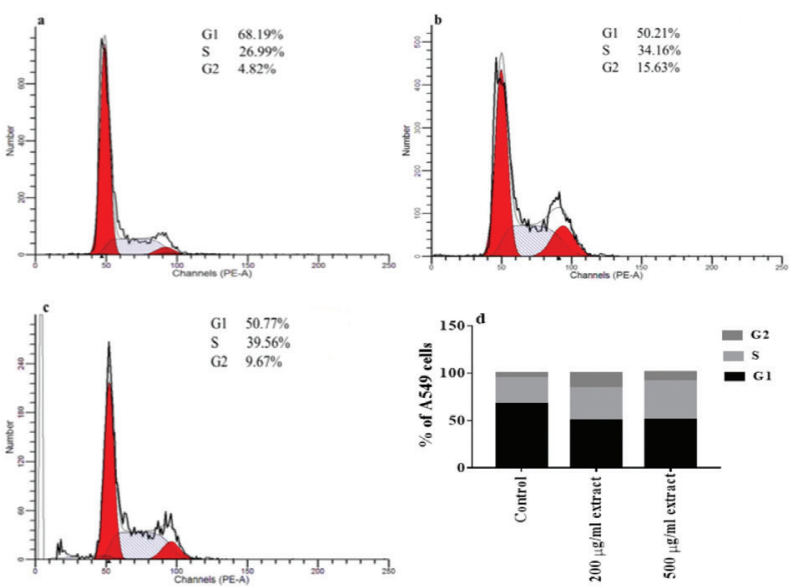

Figure 2. Effect of plant extract on cell cycle distribution of cancer cells. Histograms present a cell cycle distribution of HeLa (A) and A549 (B) cells after treatment with no extract (a), $200 \mu \mathrm{g} / \mathrm{mL}$ (b), and $500 \mu \mathrm{g} / \mathrm{mL}$ (c) extract for $24 \mathrm{~h}$. The percentages of cells at different cell cycle phases are shown $(d)$

\section{Caspase 3 activation}

Caspases play an important role in mediating various apoptotic signaling pathways. In the present study, we analyzed the activity of caspase 3 in A549 and HeLa cells treated with the extract at $500 \mu \mathrm{g} / \mathrm{mL}$ for $36 \mathrm{~h}$. As shown in Figure 4, the extract increased caspase- 3 activity about 1.65 - and 1.5-fold compared to the control in HeLa and A549 cells, respectively. These results indicate that the plant extract induces apoptosis in both of these cell lines.

\section{VEGF secretion of $A 549$ cells}

VEGF is a potent cytokine produced by many cell types including most cancer cells and it has critical roles in physiological and pathological angiogenesis. ${ }^{21}$ Because VEGF protein expression was determined in the airway epithelial cancer cell line A549 by Koyama et al., ${ }^{22}$ VEGF secretion of A549 cells was investigated after treatment with the extract at $200 \mu \mathrm{g} / \mathrm{mL}$ by human VEGF ELISA assay. The plant extract caused a 2.5 -fold decrease in VEGF secretion of A549 cells compared to untreated control

A
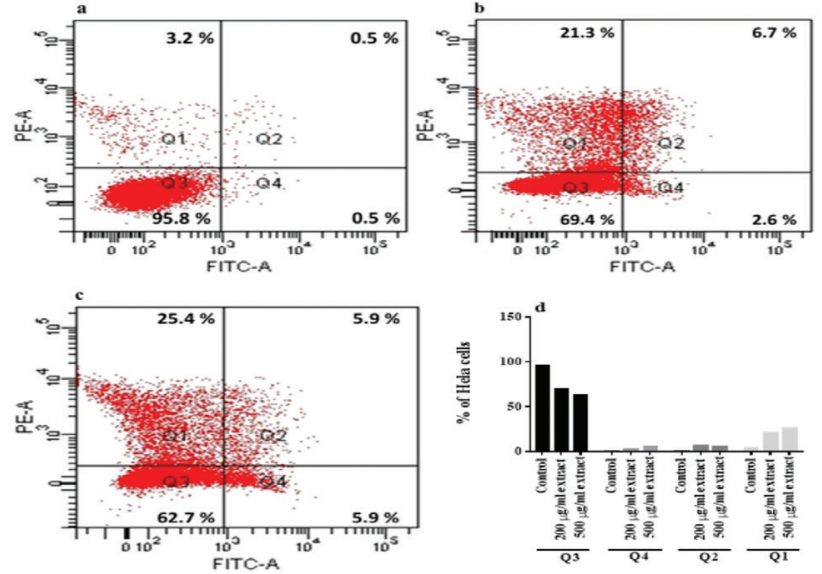

B
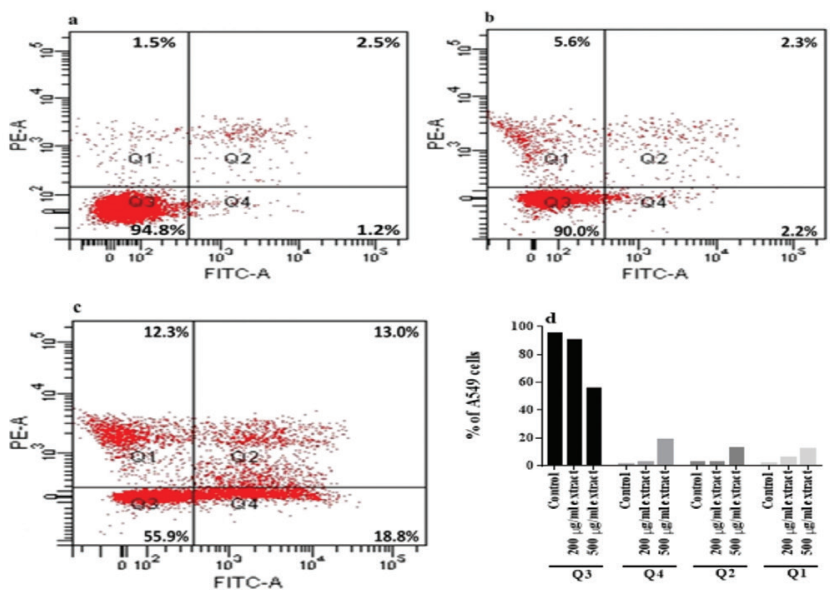

Figure 3. Plant extract induces apoptosis in cancer cells. HeLa (A) and A549 (B) cells were treated with no extract (a), $200 \mu \mathrm{g} / \mathrm{mL}$ (b), and $500 \mu \mathrm{g} /$ $\mathrm{mL}$ extract (c) for $24 \mathrm{~h}$. Cells were distributed into four quadrants: viable cells (Q3), early apoptotic cells (Q4), late apoptotic cells (Q2), and necrotic cells (Q1). The percentage of apoptotic cells (d) 
cells (Figure 5), indicating the antiangiogenic function of the extract.

\section{Effect of plant extract on IL-1 $\alpha, I L-6$, and TNF- $\alpha$ secretion}

It is known that different cytokines and growth factors may contribute to cancer progression. ${ }^{23}$ In the present study, the

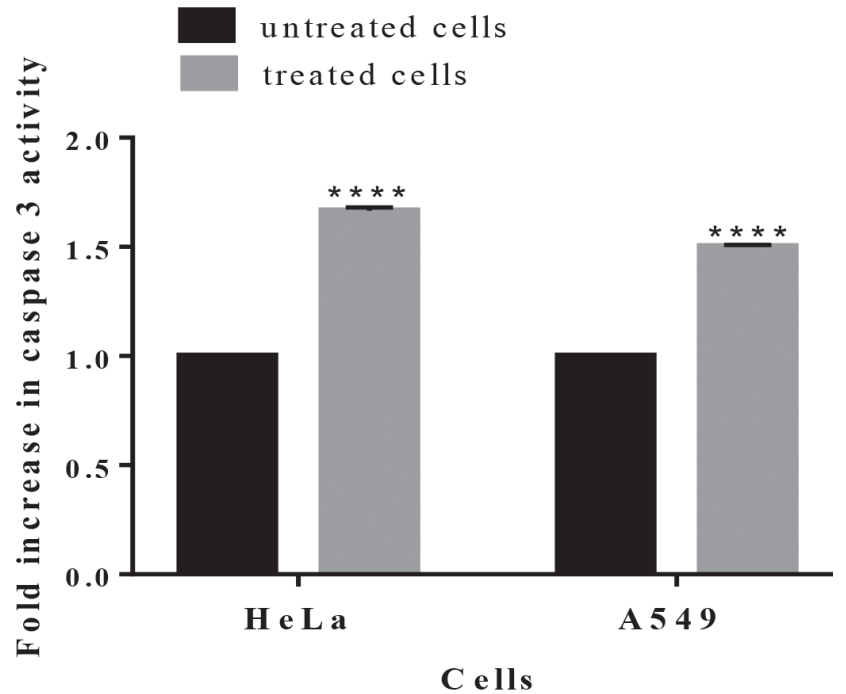

Figure 4. Caspase 3 activity in HeLa and A549 cells after treatment with the plant extract. Cells were treated without or with the extract at $500 \mu \mathrm{g} /$ $\mathrm{mL}$ for $36 \mathrm{~h}$. Caspase 3 activity in untreated cells was taken as 1-fold and the change in the treated cells was expressed by comparing untreated cells. The results are the means ( \pm standard deviation) of three independent experiments

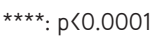

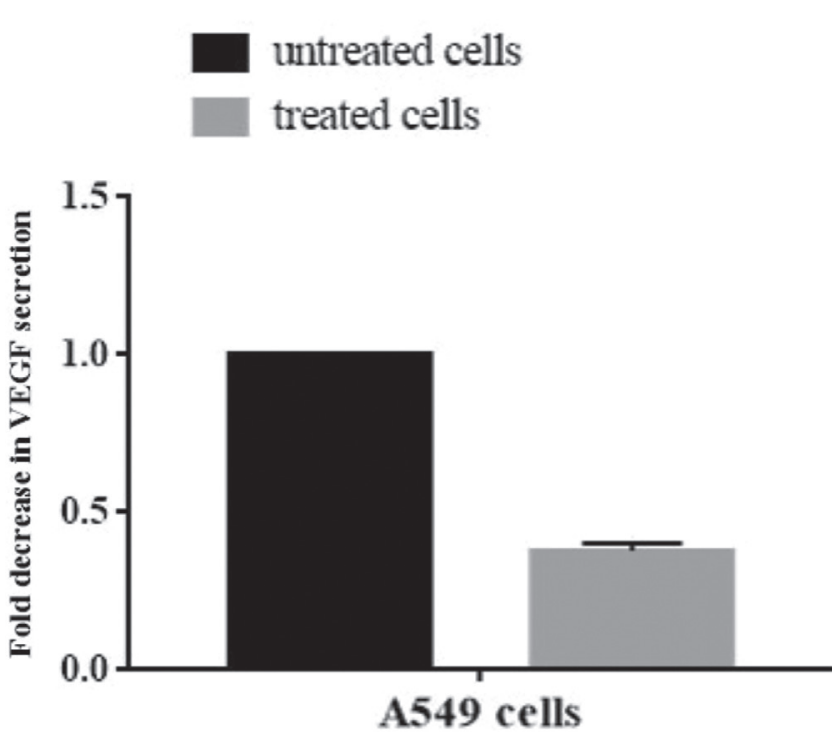

Figure 5. Effects of plant extract on vascular endothelial growth factor secretion of A549 cells. Cells were treated with $200 \mu \mathrm{g} / \mathrm{mL}$ extract for $6 \mathrm{~h}$ and vascular endothelial growth factor concentration in supernatants was detected by enzyme-linked immunosorbent assay. Results are presented as fold of change in relation to the control cells. Data are the means ( \pm standard deviation) of three independent experiments

VEGF: Vascular endothelial growth factor
IL-1 $\alpha, \mathrm{IL}-6$, and TNF- $\alpha$ concentrations in A549 and Daudi cell culture supernatants after treatment with plant extract at 200 $\mu \mathrm{g} / \mathrm{mL}$ were determined. The effect of plant extract on cytokine secretion varied according to the cell lines used. The highest level of inhibition on the release of cytokines was observed in A549 for IL-6 and Daudi for IL-1 $\alpha$ compared to untreated control cells (Figure 6). In contrast, there was a slight increase in the release of IL-1 $\alpha$ and TNF- $\alpha$ in A549 cells and IL-6 in Daudi cells.

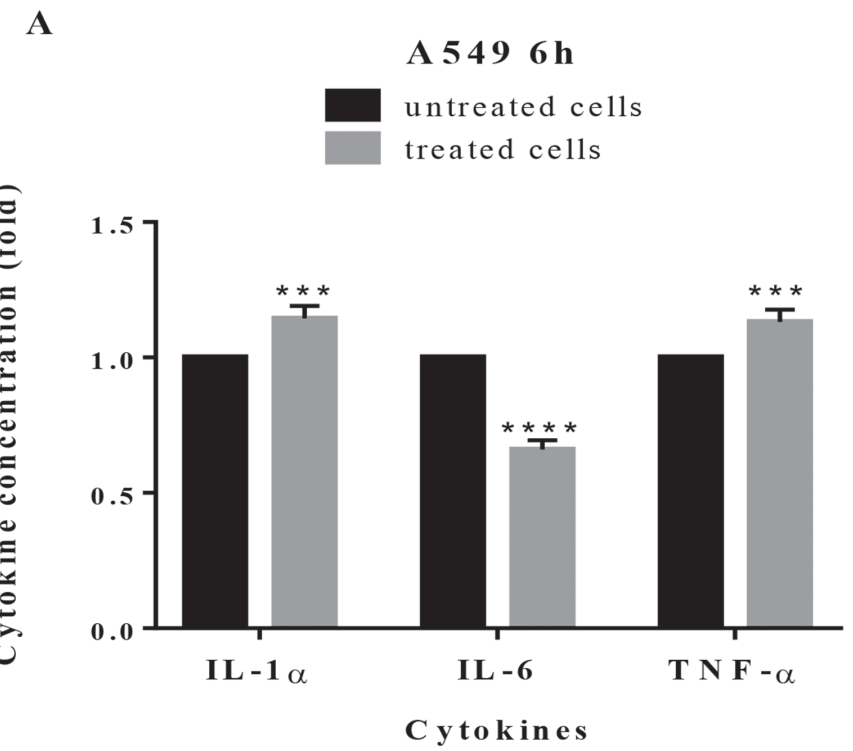

B

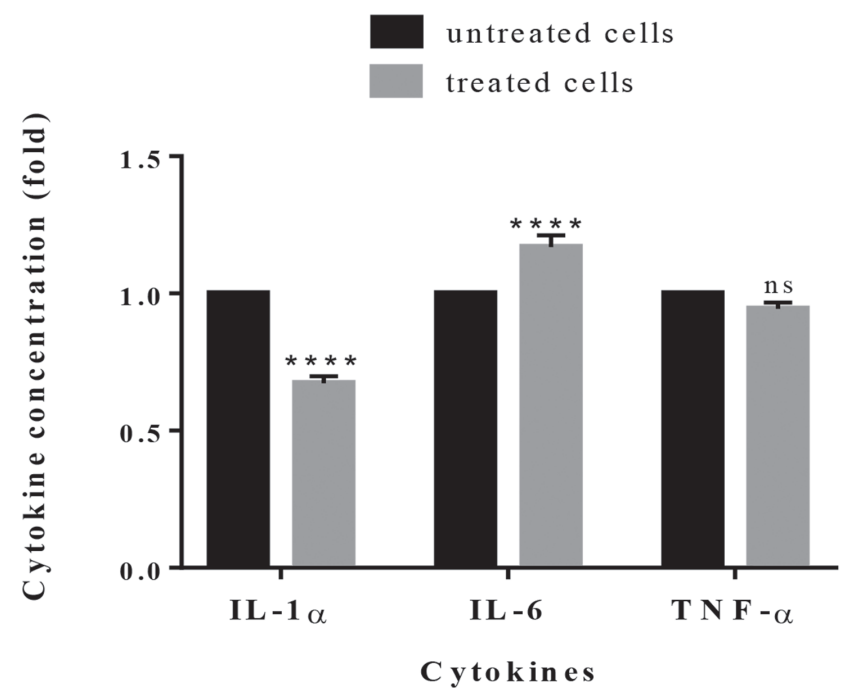

Figure 6. Effects of plant extract on cytokine secretion. A549 cells (A) and Daudi cells (B) were treated with plant extract at $200 \mu \mathrm{g} / \mathrm{mL}$ for $6 \mathrm{~h}$. The concentrations of IL-1 $\alpha, I L-6$, and tumor necrosis factor- $\alpha$ in the supernatants of cancer cells were detected by enzyme-linked immunosorbent assay. Results are presented as fold of change in relation to the control cells. Data are the means ( \pm standard deviation) of three independent experiments

${ }^{* * * *}$ : $p<0.0001,{ }^{* * *}$ : $p<0.01$, ns: nonsignificant, TNF: tumor necrosis factor, IL: interleukin 
In other words, the plant extract caused a significant change in the cytokine levels of cancer cells.

\section{DISCUSSION}

Cancer is one of the major causes of death in the world. ${ }^{24}$ It has been known for centuries that plants have anticancer properties and they are important resources for new anticancer drugs. ${ }^{25}$ The genus Centaurea has been the subject of many phytochemical and biological studies because of its widespread application in folk medicine to treat various diseases. Different biological activities such as antioxidant, ${ }^{26}$ antimicrobial, ${ }^{27}$ antipyretic, ${ }^{28}$ and anti-ulcerogenic functions ${ }^{29}$ were reported for $C$. solstitialis. However, to the best of our knowledge not much information is available about the anticancer and anti-inflammatory activities of $C$. solstitialis in the literature. Therefore, such biological activities of ethanolic extract from the flowering parts of $C$. solstitialis were examined in the present study.

Investigation of the cytotoxic effect of a plant extract against cancer cells is an important step for the development of plantbased drugs for cancer treatment. Likewise, the cytotoxic effect of ethanolic extract from the flowering parts of $C$. solstitialis on different cancer cell lines was tested. The findings indicated that plant extract showed cytotoxic effects at different levels according to the type of cell lines used. The extract exhibited the highest cytotoxicities in HeLa cells, with an $\mathrm{IC}_{50}$ value of $63.18 \mu \mathrm{g} / \mathrm{mL}$, and Daudi cells, with an $\mathrm{IC}_{50}$ value of $69.27 \mu \mathrm{g} /$ $\mathrm{mL}$, whereas the $\mathrm{IC}_{50}$ value in the BEAS-2B normal cell line was $75.25 \mu \mathrm{g} / \mathrm{mL}$. However, plant extract showed the lowest cytotoxic effect against A549 cells $\left(\mathrm{IC}_{50}\right.$ value of $252.5 \mu \mathrm{g} /$ $\mathrm{mL}$ ). Erenler et al. ${ }^{30}$ investigated the antiproliferative activities of methanol extract of the root, stem, and flowering parts of C. solstitialis L. subsp. solstitialis on C6 cells and HeLa cells in vitro and found that the methanol extract of the stem exhibited the most antiproliferative activity. In contrast to their study, our previous investigation demonstrated that the flowers were a more effective plant part compared to the stem (unpublished data) and so ethanolic extract only from the flowering parts was used in the present study. The reason for this may have been the type of solvent used for extract preparation. In fact, different solvents result in extraction of chemical compounds at different scales.

Similar to this study, there are publications related to different Centaurea species that have cytotoxic effects against the A549 and HeLa cell lines. Tugba Artun et al. ${ }^{31}$ reported that among 14 plant extracts the methanol extract of Centaurea nerimaniae exhibited the highest cytotoxic effect against the Vero normal cell line and methanolic extract of the endemic Centaurea antiochia Boiss. var. praealta showed a selective cytotoxic effect against the HeLa cell line, with an $I_{50}$ value of $427 \pm 3.06 \mu \mathrm{g} /$ $\mathrm{mL}$. In another study, chloroform extracts of Centaurea cadmea showed the most inhibitory activities against the HeLa $\left(\mathrm{IC}_{50}\right.$ : $14.24 \mu \mathrm{g} / \mathrm{mL}), A 549\left(\mathrm{IC}_{50}: 35.00 \mu \mathrm{g} / \mathrm{mL}\right)$, and U20S $\left(\mathrm{IC}_{50}: 43.10\right.$ $\mu \mathrm{g} / \mathrm{mL}$ ) human cancer cell lines and the 293HEK (IC ${ }_{50}: 23.50$ $\mu \mathrm{g} / \mathrm{mL}$ ) noncancer cell line..$^{32}$ In addition, Zater et al..$^{33}$ stated that chloroformic extract of $C$. diluta Ait. subsp. algeriensis exhibited more significant cytotoxic effects on the cancer cells A549, MCF-7, and U373 than the isolated pure compounds. Taken together, these studies indicate that the cytotoxicity level changes depending on the different Centaurea species and solvents used for extract preparation and the type of cell lines used for the in vitro cytotoxicity test.

Because cell cycle inhibition is a main target in the development and discovery of a drug against cancer, the effect of plant extract on the cell cycle progression of the HeLa and A549 cell lines after $24 \mathrm{~h}$ treatment was investigated in the present study. The results indicated that the plant extract blocked cancer cell proliferation by arresting both cell lines especially in the G2 phase of the cell cycle. In contrast to our results, Ghantous et $a .^{34}$ reported that inhibition of the cell proliferation of the papilloma and squamous cell carcinoma cell lines by crude extract of Centaurea ainetensis and the compound salograviolide A isolated from this plant was due to G0/G1 cell cycle arrest. Other researchers demonstrated that crude extract of Centaurea ainetensis induced a progressive increase in the proportion of sub-G1 cells in the HCT-116 cell line. ${ }^{35}$

Apoptosis is an important physiological process that plays a critical role in development and homeostasis in normal tissues; however, the balance between cell division and apoptosis is lost in cancer. ${ }^{36,37}$ Therefore, targeting apoptosis in cancer treatment is crucial. In cells undergoing apoptosis, phosphatidylserine (PS) translocates toward the extracellular side of the membrane. Annexin $V$ is a phospholipid-binding protein and so translocation of PS to the outside of the membrane is detected by Annexin $V$ staining and it shows early stage apoptosis. ${ }^{38}$ In the literature, only two studies investigated the apoptotic effects of extracts from Centaurea ainetensis ${ }^{34}$ and Centaurea fenzlii Reichardt ${ }^{39}$ on different cancer cell lines and they showed the presence of apoptotic cell death. In the present study, Annexin V staining along with flow cytometric analysis was carried out to reveal the mechanism in the cytotoxicity of plant extract on the A549 and HeLa cancer cells. Similar to previous studies, treatment of HeLa and A549 cells with C. solstitialis extract induced apoptosis and increased apoptotic cell number in a dose-dependent manner (Figure 3).

Caspases, a family of proteases, play an essential role in the apoptotic pathway and become activated during the early stages of apoptosis. ${ }^{40}$ Because elevation in caspase- 3 activity is regarded as an apoptotic marker, caspase- 3 activity in treated and untreated cancer cell lines was examined. The results indicated that ethanolic extract of the flowering parts of $C$. solstitialis caused an increase in caspase- 3 activity in both the HeLa and A549 cell lines (Figure 4). In addition, Yırtıcı et al. ${ }^{39}$ reported that dichloromethane extracts-ethyl acetate fractions from $C$. fenzlii Reichardt exhibited an apoptotic effect on MCF-7 cells using flow cytometry and western blot analysis of an apoptosis-related protein, adenosine diphosphate ribose polymerase.

Angiogenesis is defined as the formation of new microvessels from preexisting ones and is required for tumor growth and distribution of tumor cells to distant locations. ${ }^{41}$ VEGF is known 
to be one of the most potent angiogenic factors. Previous studies indicated that inhibition of VEGF secretion suppresses tumor growth, tumor invasion, and metastasis. ${ }^{41}$ A549, an airway epithelial cancer cell line, releases VEGF constitutively. ${ }^{22}$ Therefore, the angiogenic potential of the extract on the A549 cell line was investigated by measuring VEGF secretion after $6 \mathrm{~h}$ of treatment. A significant inhibition of VEGF secretion in A549 cells implies that the plant extract has potential as an anti-angiogenic agent in cancer therapy.

Inflammatory cytokines play a role in different stages of tumor development and many cytokines such as TNF, IL-1, and IL-6 can be induced by hypoxia, one of the well known properties of cancer cells. ${ }^{42,43}$ Here we tested the effect of plant extract on the secretion of IL-1 $\alpha, \mathrm{IL}-6$, and TNF- $\alpha$ in A549 and Daudi cells. The plant extract at $200 \mu \mathrm{g} / \mathrm{mL}$ did not decrease TNF- $\alpha$ production in either cell line (Figure 6). The plant extract significantly inhibited the release of IL-6 in A549 and the release of IL-1 $\alpha$ in Daudi cells. According to a previous study, production of angiogenic factors such as VEGF could be induced by TNF, IL-1, and IL- 6. ${ }^{42}$ A decrease in VEGF production in A549 cells may be associated with decreased IL-6 production in A549 cells in the present study. Similar to our result, Talhouk et al. ${ }^{44}$ reported that water extract of $C$. ainetensis inhibited IL-6 production in a dose-dependent manner. In addition, in vivo anti-inflammatory effects of some Centaurea species were reported as well by Erel et al. ${ }^{45}$ and Koca et al. ${ }^{46}$ The present study indicates that induction or inhibition of inflammatory cytokines by ethanolic extract of $C$. solstitialis is cell-type dependent.

\section{Study limitations}

Crude ethanolic extract from the flowering parts of $C$. solstitialis was investigated for its anticancer and anti-inflammatory potential. Isolation of pure compounds in a future study will show if each constituent alone or in different combinations may exhibit increased anticancer or anti-inflammatory activities.

\section{CONCLUSIONS}

Ethanolic extract from the flowering parts of $C$. solstitialis showed significant anticancer and anti-inflammatory potential against different cancer cell lines, indicating that the flowering parts of $C$. solstitialis are a potential source of active compounds for the development of natural drugs against cancer.

\section{ACKNOWLEDGEMENT}

This work was supported by grants 15/006 and 15/247 from Scientific Research Projects (BAP) of Muğla Sıtkı Koçman University

Conflict of Interest: No conflict of interest was declared by the authors.

\section{REFERENCES}

1. Raskin I, Ribnicky DM, Komarnytsky S, llic N, Poulev A, Borisjuk N, Brinker A, Moreno DA, Ripoll C, Yakoby N, O'Neal JM, Cornwell T, Pastor I, Fridlender B. Plants and human health in the twenty-first century. Trends Biotechnol. 2002;20:522-531.
2. Unnati S, Ripal S, Sanjeev A, Niyati A. Novel anticancer agents from plant sources. Chin J Nat Med. 2013;11:16-23.

3. Fan TP, Yeh JC, Leung KW, Yue PY, Wong RN. Angiogenesis: from plants to blood. Trends Pharmacol Sci. 2006;27:297-309.

4. Tahergorabi Z, Khazaei M. A Review on Angiogenesis and Its Assays. Iran J Basic Med Sci. 2012;15:1110-1126.

5. Schottenfeld D, Beebe-Dimmer J. Chronic Inflammation: A Common and Important Factor in the Pathogenesis of Neoplasia. CA Cancer J Clin. 2006;56:69-83.

6. Oppenheim JJ, Murphy WJ, Chertox O, Schirrmacher V, Wang JM. Prospects for Cytokine and Chemokine Biotherapy. Clin Cancer Res.1997;3:2682-2686.

7. Hollman, PC, Katan MB. Dietary Flavonoids: intake, health effects and bioavailability. Food Chem Toxicol.1999;37:937-942.

8. Thun MJ, Henley, SJ, Patrono C. Nonsteroidal Anti-inflammatory Drugs as Anticancer Agents: Mechanistic, Pharmacologic, and Clinical Issues. J Natl Cancer Inst. 2002;94:252-266.

9. Güner A, Özhatay N, Ekim T, Başer K. Flora of Turkey and the East Aegean Islands. Vol 11. Edinburgh: Edinburgh University Press;2000.

10. Altundag E, Ozturk M. Ethnomedicinal studies on the plant resources of east Anatolia. Procedia Soc Behav Sci. 2011;19:756-777.

11. Honda G, Yeşilada E, Tabata M, Sezik E, Fujita T, Takeda Y, Takaishi Y, Tanaka T. Traditional medicine in Turkey VI. Folk medicine in West Anatolia: Afyon, Kütahya, Denizli, Muğla, Aydın provinces. J Ethnopharmacol. 1996;53:75-87.

12. Sezik E, Yeșilada E, Honda G, Takaishi Y, Takeda Y, Tanaka T. Traditional medicine in Turkey X. Folk medicine in Central Anatolia. J Ethnopharmacol. 2001;75:95-115.

13. Bulut G, Tuzlaci E. An ethnobotanical study of medicinal plants in Turgutlu (Manisa-Turkey). J Ethnopharmacol. 2013;149:633-647.

14. Fujita T, Sezik E, Tabata M, Yeşilada E, Honda G, Takeda Y, Tanaka T, Takaishi Y. Traditional Medicine in Turkey VII.Folk Medicine in Middle and West Black Sea Regions. Econ Bot. 1995;49:406-422.

15. Khammar A, Djeddi S. Pharmacological and Biological Properties of some Centaurea Species. Eur J Sci Res. 2012;84:398-416.

16. Kaïj-a-Kamb M, Amoros M, Girre L. The chemistry and biological activities of the genus Centaurea. Pharm Acta Helv. 1992;67:178-188.

17. Aktumsek A, Zengin G, Guler GO, Cakmak YS, Duran A. Screening for in vitro antioxidant properties and fatty acid profiles of five Centaurea $L$. species from Turkey flora. Food Chem Toxicol. 2011;49:2914-2920.

18. Denizot F, Lang R. Rapid colorimetric assay for cell growth and survival: Modifications to the tetrazolium dye procedure giving improved sensitivity and reliability. J Immunol Methods. 1986;89:271-277.

19. Bradford, MM. A Rapid and Sensitive Method for the Quantitation of Microgram Quantities of Protein Utilizing the Principle of Protein-Dye Binding. Anal Biochem. 1976;72:248-254.

20. Hengartner, MO. The biochemistry of apoptosis. Nature. 2000;407:770776.

21. Chung AS, Ferrara N. Developmental and Pathological Angiogenesis. Annu Rev Cell Dev Biol. 2011;27:563-584

22. Koyama S, Sato E, Tsukadaira A, Haniuda M, Numanami $H$, Kurai M, Nagai S, Izumi T. Vascular endothelial growth factor mRNA and protein expression in airway epithelial cell lines in vitro. Eur Respir J. 2002;20:1449-1456. 
23. Dranoff G. Cytokines in cancer pathogenesis and cancer therapy. Nat Rev Cancer. 2004;4:11-22.

24. World Health Organization. World health statistics 2017: monitoring health for the SDGs, Sustainable Development Goals. Geneva: World Health Organization; 2017.

25. Cragg GM, Newman DJ. Natural products: A continuing source of novel drug leads. Biochim Biophys Acta. 2013;1830:3670-3695.

26. Tekeli $Y$, Sezgin M, Aktümsek A. Antioxidant property of Centaurea solstitialis L. from Konya, Turkey. Asian J Chem. 2008;20:4831-4835.

27. Özçelik B, Gürbüz I, Karaoglu T, Yeșilada E. Antiviral and antimicrobial activities of three sesquiterpene lactones from Centaurea solstitialis L. ssp. solstitialis. Microbiol Res. 2009;164:545-552.

28. Akkol EK, Arif R, Ergun F, Yesilada E. Sesquiterpene lactones with antinociceptive and antipyretic activity from two Centaurea species. J Ethnopharmacol. 2009;122:210-215.

29. Gürbüz I, Yesilada E. Evaluation of the anti-ulcerogenic effect of sesquiterpene lactones from Centaurea solstitialis L. ssp. solstitialis by using various in vivo and biochemical techniques. J Ethnopharmacol. 2007;112:284-291.

30. Erenler R, Sen O, Yaglioglu AS, Demirtas I. Bioactivity-Guided Isolation of Antiproliferative Sesquiterpene Lactones from Centaurea solstitialis L. ssp. solstitialis. Comb Chem High Throughput Screen. 2016;19:66-72.

31. Tugba Artun F, Karagoz A, Ozcan G, Melikoglu G, Anil S, Kultur S, Sutlupinar N. In vitro anticancer and cytotoxic activities of some plant extracts on HeLa and Vero cell lines. J BUON. 2016;21:720-725.

32. Astari KA, Erel ŞB, Köse FA, Köksal Ç, Karaalp C. Cytotoxic and Antibacterial Activities of Centaurea cadmea Boiss. Turk J Pharm Sci. 2014:11:101-106.

33. Zater $\mathrm{H}$, Huet J, Fontaine V, Benayache S, Stévigny C, Duez P, Benayache F. Chemical constituents, cytotoxic, antifungal and antimicrobial properties of Centaurea diluta Ait. subsp. algeriensis (Coss. \& Dur.) Maire. Asian Pac J Trop Med. 2016;9:554-561.

34. Ghantous A, Tayyoun AA, Lteif GA, Saliba NA, Gali-Muhtasib H, ElSabban M, Darwiche N. Purified Salograviolide A isolated from
Centaurea ainetensis causes growth inhibition and apoptosis in neoplastic epidermal cells. Int J Oncol. 2008;32:841-849.

35. El-Najjar N1, Dakdouki S, Darwiche N, El-Sabban M, Saliba NA, GaliMuhtasib H. Anti-colon cancer effects of Salograviolide A isolated from Centaurea ainetensis. Oncol Rep. 2008;19:897-904.

36. Hanahan D, Weinberg RA. The Hallmarks of Cancer. Cell. 200;100:57-70.

37. Plati J, Bucur O, Khosravi-Far R. Apoptotic cell signaling in cancer progression and therapy. Integr Biol (Camb). 2011;3:279-296.

38. Deepa M, Sureshkumar T, Satheeshkumar PK, Priya S. Purified mulberry leaf lectin (MLL) induces apoptosis and cell cycle arrest in human breast cancer and colon cancer cells. Chem Biol Interact. 2012;200:38-44.

39. Yırtıcı Ü, Göger F, Sarımahmut M, Ergene A. Cytotoxic and apoptotic effects of endemic Centaurea fenzlii Reichardt on the MCF-7 breast cancer cell line. Turk J Biol. 2017;41:370-377.

40. Porter AG, Jänicke RU. Emerging roles of caspase-3 in apoptosis. Cell Death Differ. 1999;6:99-104.

41. Masoumi Moghaddam S, Amini A, Morris DL, Pourgholami MH. Significance of vascular endothelial growth factor in growth. Cancer Metastasis Rev. 2012;31:143-162.

42. Balkwill F, Mantovani A. Inflammation and cancer: back to Virchow? Lancet. 2001;357:539-545.

43. Fernandes JV, Cobucci RN, Jatobá CA, Fernandes TA, de Azevedo JW, de Araújo JM. The Role of the Mediators of Inflammation in Cancer Development. Pathol Oncol Res. 2015;21:527-534.

44. Talhouk RS, El-Jouni W, Baalbaki R, Gali-Muhtasib H, Kogan J, Talhouk SN. Anti-inflammatory bio-activities in water extract of Centaurea ainetensis. J Med Plant Res. 2008;2:24-33.

45. Erel SB, Demir S, Nalbantsoy A, Ballar P, Khan S, Yavasoglu NU, Karaalp C. Bioactivity screening of five Centaurea species and in vivo antiinflammatory activity of C. athoa. Pharm Biol. 2014;52:775-781.

46. Koca U, Süntar IP, Keles H, Yesilada E, Akkol EK. In vivo anti-inflammatory and wound healing activities of Centaurea iberica Trev.ex Spreng. J Ethnopharmacol. 2009;126:551-556. 